\title{
Lost Beasts of Britain, by Anthony Dent. Harrap. $£ 2.85$
}

The author's main interest is in folklore and the byways of history, and it is with these in view that he has hunted down many fascinating references to the days when the beaver, the wild boar, the wild cat and the wolf were living members of the fauna of England. Despite the title the book deals mainly with England, or rather Roman Britain north to the Antonine Wall, for the wild cat is still, of course, a most vigorous member of the fauna in the Scottish Highlands. The introduction deals also with some other creatures that are not lost beasts here, such as the reindeer and wild cattle, and even the great auk, which is not a beast. The author is also out of touch with modern Britain in not knowing that the pine marten still exists in England and the polecat in Wales - he says it 'may be there still', but did not trouble to check with any modern book on British mammals. But if naturalists may have a few complaints, lovers of folklore and historical byways will have a most excellent read.

RICHARD FITTER

Thorburn's Mammals. Introduced by David Attenborough, notes by Iain Bishop. Ebury Press, $£ 3.95$

Animals of the Dark, by Clive Roots. David \& Charles, $£ 3.50$

Ethology of Mammals, by R. F. Ewer. Elek Science, $£ 2.80$ (paper bound)

The publication of Archibald Thorburn's British Mammals in 1920-21 marked almost the end of a period of intense interest in the subject, a period that saw such lavish and ambitious publications as Millais's three volumes of The Mammals of Great Britain and Ireland in 1904-06 and Barrett-Hamilton and Hinton's unfinished History of British Mammals between 1910 and 1921. This interest arose primarily as a byproduct of the fashion for 'wild sports', and its decline can perhaps be correlated with the upsurge of observational ornithology that replaced the earlier collecting mania. The last twenty years have seen a considerable renewal of interest in British mammals but have not yet produced any single set of illustrations to match Thorburn's. It is therefore very pleasing to have the complete set reproduced in a single volume. All fifty colour plates have been included, at half the original size, depicting seventy species (by present classifications). Some of the softness of the originals has been lost but the detail and the unique atmosphere remain.

The inclusion of Thorburn's text, verbatim, is of more dubious value. Many readers will enjoy the many snippets of history and behaviour that are so characteristic of the writings of this period; others may well overlook its antiquity and be misled. Polecats, alas, are no longer even 'very scarce' in Scotland, horseshoe bats are unlikely to be seen in London's central parks, and giant house mice no longer find shelter in the cleits of St Kilda. The nomenclature (already rather archaic in 1921) is unaltered in the main text but is brought up to date in the appendix by Iain Bishop, who has also added useful short notes on additional species such as the whitetoothed shrews and the introduced mink, grey squirrel, fat dormouse and coypu.

Animals of the Dark is a serious, non-technical, but rather pedestrian account of a selection of nocturnal vertebrates from many parts of the world, with the emphasis on amphibians, reptiles and mammals. Many aspects of the behaviour of the animals concerned remain a closed book because of the difficulties inherent in studying nocturnal animals in the wild. This account, however, does little to penetrate the darkness and contains little that is not to be found amongst the abundance of popular reference books on these groups.

By contrast, in spite of the technical flavour of the title, the general naturalist will find much fascination (and little difficulty) in perusing Ethology of Mammals, first published in 1968 and reprinted in paper and hard covers. Ethology is the study of animal behaviour and especially its correlation with the animal's structure and natural environment. Someone approaching this book from the point of view of a 
field naturalist may be surprised to find the author stressing the apparently obvious connection between behaviour and ecology, until further reading makes it clear just how much of behavioural research is divorced from the realities of natural environment. Dr Ewer draws her examples from all groups of mammals, and is at pains to emphasise the existence, and indeed the necessity, of an extensive and complex basis of innate behaviour patterns as a prerequisite for the learning ability that so characterises the mammals.

GORDON B. CORBET

The Changing Flora and Fauna of Britain, edited by D. L. Hawksworth. Academic Press for the Systematics Association, $£ 9.20$

The last two decades have probably witnessed the most intensive period of activity in the study of the taxonomy and distribution of our flora and fauna since the closing years of the last century. The origins of this resurgence of interest in the more 'traditional' areas of field ecology can be attributed on one hand to concern over the impacts of a rapidly changing countryside and new forms of pollution, and on the other to the impetus of the introduction by the Biological Records Centre at Monk's Wood of mechanical data storage and retrieval techniques. Nine of the contributors to the present Symposium illustrated distributions by means of the BRC's standard $10 \mathrm{~km} \times 10 \mathrm{~km}$ dot maps.

Twenty taxonomic groups are reviewed from micro-fungi to arthropod parasites of man. Some of the material, for example on vertebrates will already be familiar, but much of the information on other groups has never before been collated. Oryx readers will especially welcome the chapters on freshwater fish by Wheeler and amphibians and reptiles by Prestt, Cooke and Corbett. The symposium lends support to the generally accepted view that many species of a broad range of taxonomic groups have suffered serious declines in the last 50 years while some are known to have become extinct. However, the story is not all gloom and additions to the fauna seem to be more than making up for the losses. "More species (birds) are now breeding regularly in Britain and Ireland than at any time since ornithological recording began'.

Perhaps the book's most valuable feature is the analysis of the reasons for recent changes in status. The problems of sorting out effects due to natural causes, such as climatic changes, and those caused more directly by our own activities, for example damage to habitat and pollution, are not always easy. However, it is accepted that many taxonomic groups are sensitive indicators of environmental change and indeed this fact now provides one of the most potent arguments supporting the case for wildlife conservation.

The organisers hoped that the symposium would increase the awareness of specialist taxonomists to changes in groups of organisms other than their own and the causes for these. This has certainly been achieved and more. Conservationists and all concerned with the management of our countryside now have a uniquely valuable account of the present status of the British flora and fauna.

D. T. STREETER

\section{Freshwater Life, by John Clegg. Warne, $£ 6.00$}

The appearance of the fourth edition of this book first published 25 years ago underlines its success. The author has taken the opportunity to extend and revise the text to include recent advances in freshwater biology and to accommodate changes in the approach to the study of the subject. The book continues to give a comprehensive description of the biology of the major plant and animal groups and of selected species. It also includes chapters on freshwater ecology, the biological aspects of 